\title{
Professional language competence of technical university students: concept, its specificity and development
}

\section{Competencia lingüística profesional de estudiantes de universidades técnicas: concepto, especificidad y desarrollo}

Andrey A. Gareyev ${ }^{1}$

\begin{abstract}
The objective of this paper is to provide a strict definition of a concept "competence" which can be used in the context of professional language training of technical university students. The literature review shows the necessity of the development of professional language competence in future tool-making engineers that technical universities in Russia train. Based on this review, the structure of this competence has been identified. Also, the process of professional language competence development is thoroughly analyzed so that the conclusions about the stages of this process and the necessary pedagogical conditions that a teacher must follow are determined.
\end{abstract}

Keywords: professional language competence, technical university, competency-based approach, professional technical training

\section{Resumen}

El objetivo de este artículo, es proporcionar una definición estricta del concepto de "competencia", que se puede utilizar en el contexto de la formación en idiomas de estudiantes de universidades técnicas. La revisión de la literatura muestra la necesidad del desarrollo de la competencia lingüística profesional, en los futuros ingenieros fabricantes de herramientas de las universidades técnicas en Rusia. Con base en esta revisión, se ha identificado la naturaleza

\footnotetext{
${ }^{1}$ Senior instructor in M.T. Kalashnikov Izhevsk State Technical University. ORCID: 0000-0002-4969-1012. andrei.gareeff@yandex.ru

Recibido 06 de octubre de 2019 / Aceptado 31 de noviembre de 2019 
y el proceso de desarrollo de la competencia lingüística profesional. Adicionalmente, se determinan las condiciones pedagógicas necesarias que un maestro debe seguir para el logro de esta capacidad.

Palabras clave: competencia lingüística profesional, universidad técnica, enfoque basado en competencias, formación técnico profesional

\section{Introduction}

With higher education institutions adopting the competency-based approach, pedagogical science today views students' education as the process of their competencies' development.

According to Zeer, competency-based approach is "a focus on goals-vectors of education: learning ability, self-determination, self-actualization, socialization and personality development" (Zeer, 2005, p. 29). In our paper, an attempt to clarify the concept of competence in the context of professional language training of technical university undergraduates is studied.

Education experts claim that the concept of competence has been introduced to facilitate the discussion and collaboration of higher educational institutions with the labour market whose views differ in determining what skills future university graduates should be trained for. To eliminate this contradiction, the idea of competence has been applied to the educational process to mean the results of education which can be assessed objectively. The dialogue between educational institutions and employers must have been aimed at establishing "a unified educational, professional-qualificational and value-cultural environment" that would improve academic and professional mobility of university graduates (Baidenko, 2005, p. 11).

At the same time, the fact that competencies correspond to the specific learning outcomes does not mean they are equivalent: learning outcomes are just expected and measurable components of competencies (Petrova et al., 2013).

The latest federal state educational standards of higher education (FSES HE) in Russian 
Federation specify a list of universal, general-professional and specific-professional competencies as planned learning outcomes, with a great emphasis on developing universal competencies. However, given the multifaceted and integrative nature of competence, it is reasonable to assume that a more rational and relevant approach would be to develop all groups of competencies simultaneously, including the profession-related ones.

\section{Literature review}

\section{Concept of competence}

Russian researchers highlight the integrative nature of competence and view this concept as:

1. "integrity of knowledge and skills that provide the ability to perform a professional activity” (Zeer \& Symanyuk, 2005, p. 22);

2. "ability and willingness to demonstrate flexibility in changing conditions of a labour market" (Galyamina, 2004, p. 110);

3. "general characteristic of personality" which demonstrates one's knowledge, skills and experience "in a specific social or professional area" (Medvedev \& Tatur, 2007, p. 46);

4. "a component of personal quality, a certain group of its properties which determine one's ability ... to perform a certain group of actions or tasks within a specific type of activity" (Subetto, 2009, p. 103).

The integrity of competence is expressed in the fact that many researchers include in its structure not only cognitive (knowledge) and operational (skills) components, but also motivational, ethical, behavioural and other components (Prahova et al., 2015; Tatur, 2004; Zimnyaya, 2004). Moreover, the transition from the knowledge-based paradigm to the competency-based paradigm reveals the expanded meaning of this concept. Originally, only linguists discussed competencies referring to the idea of "communicative competence". In 1970-90s the concepts of professional and social competence became more common. Nowadays, the competencies with more extended content, such as professional language competence (Gareyev et al., 
2018), are becoming more relevant.

The literature review of the concept "competence" has shown that the definition by A. Subetto is the most suitable in the context of our research. Not only does it fully reflect the qualimetric nature of this concept, but also takes into account the peculiarities of technical training of future tool-making engineers, one of the most relevant specializations in the regional and federal labour markets.

The advantage of Subetto's definition over others in scientific literature is its connection between learner's skills and qualities that determine the competence level and this competence's performance. This conceptual difference outlined in 1965 by Chomsky (2014), one of the originators of competency-based approach, in his Aspects of the Theory of Syntax is both historically significant for professional pedagogy and adds the necessary strictness to this concept's usage under the conditions of a real educational process and in scientific studies.

From this perspective and with the purpose of high-quality technical university students' training in such a priority major as radio engineering, a certain level of competence must demonstrate what professional tasks they are capable to perform, insofar as their professional activity is highly practice-oriented.

\section{Structure of profesional lenguaje competence}

Based on the ideas above, the concept of professional language competence will be discussed in the context of future engineer's training. For this, the two constituents of this concept should be clarified: "professional" and "language".

The review of studies on the development of foreign language competence concludes that the majority of researchers discuss the concept of foreign language communicative competence (FLCC). However, as the researchers themselves point out, there is still no consensus about both the definition of this competence and its component-based structure.

The key characteristics of FLCC must be identified with its components that are relevant to us in the context of professional training of future technical university graduates. Traditionally, 
FLCC means the ability to communicate, participate in a foreign language speaking activity, the knowledge and ability to use the language patterns adequate to a given situation (Gez \& Frolova, 2008).

Russian researchers define FLCC as the ability and willingness to speak in a foreign language, understand communication parties, and adequate and timely expression of one's intentions (Tayurskaya, 2015). At the same time, this competence can be developed due to the process of acquiring complex communicative skills while ethical and social norms are followed (Zimnyaya, 2004).

Structurally, in Russian-based methodology for teaching foreign languages, the following components of foreign language communicative competence are relevant for engineering training:

a) linguistic or language component: the main component of FLCC responsible for grammatically, lexically, and syntactically adequate language forms used by a subject following the rules of the foreign language;

b) speaking or discourse component: demonstrates the level of development of different types of speech (reading, writing, speaking, listening);

c) sociolinguistic: characterizes the ability to choose and use the necessary language forms adequate to a communicative situation, objectives and intentions of a subject;

d) cognitive: points to the ability to develop one's competence by oneself, self-learning skills, including the use of information and communication technologies (ICT).

Apart from these components, in the literature there are also: sociocultural component related to the understanding of cultural aspects of a target language; social component revealed by the willingness to communicate and manage a linguistic situation; and strategic component - meaning the ability to make up for the lack of linguistic knowledge and skills (Tayurskaya, 2015). However, given the special character of foreign language training in a technical university, these components are eliminated from consideration due to their irrelevance 
to the professional activity of technical university graduates. For instance, an engineer who works mainly with technical documentation and deals primarily with professional issues needs only basic knowledge about a foreign culture. The willingness to communicate and the compensation of the lack of skills are considered insignificant for the development of professional language competence of future technical university graduates. Therefore, in this article, only the components of foreign language competence which are the most relevant to a future tool-making engineer are taken into account and those considered less significant for their professional activity are not.

Interestingly, one of the key components of FLCC, a cognitive one, is rarely viewed as significant by language experts (Tayurskaya, 2015). Supposedly, it can be explained by two factors. Firstly, the studies on FLCC have been conducted mainly in the context of training the linguistic specialists or foreign language teachers. Secondly, it is rather challenging to assess the quality of students' learning activity in their out-of-classroom independent work. However, the trends of changes in higher education and the growing unpredictability of Russian and global economies require that students' independent work, which plays a particular role in their competence development, be reorganized and stimulated.

It is worth mentioning that viewing the questions of students' cognitive activity and development of their communication skills in a separate manner does not mean their parallel, separate nature. Vygotsky (1997), based on his extensive theoretical and empirical experience, criticizes his contemporary colleagues who viewed genetic roots of thinking and speech separately while their relationship must be viewed as complex and interdependent.

Sharing the view of Vygotsky, the author of this article still views cognitive and communicative components separately, but only from functional, not genetic, perspective. It should be noted that this separated view is artificial and aimed only at implementing the principles of diagnosticity and measurability of competencies.

Over the last ten years, a small segment of research is focused on developing foreign language competence as part of professional training of non-linguistic university students, technical 
university students in particular. In Russian pedagogical literature this trend is linked to the decrease in the number of classroom academic hours for the discipline "Foreign Language (professional translation)" or related ones which are professionally oriented, so that it caused the need for new models and technologies that would allow organizing students' independent work (Medvedev \& Tatur, 2007). More than that, the technical focus of the research on foreign language training of future engineers becomes more evident in the latest editions of FSES $\mathrm{HE}$ and professional standards for engineering majors and professions.

Thus, the particulars of the process of development of profession-oriented FLCC for future technical university graduates has been studied. Scientific literature reveals a number of approaches to describe the structure of FLCC applicable to students' professional training. For instance, S. Chichilanova (2010) has identified three criteria of students' professionoriented FLCCs developed over the course of their independent work:

e) meaning-related: how well a student conveys the meaning and intention of a speaker, listens to and translates technical texts from English into Russian;

f) linguistic: how well a student uses linguistic means: lexical, grammatical, syntactical and phonetical;

g) strategic: how well a student plans, organizes and critically assesses one's own activity. Mukharkina (2008) while studying the process of development of intercultural communicativeprofessional competence distinguishes its components as follows:

- motivational: intrinsic (conscious or unconscious) needs towards learning about a foreign culture compared to the native one;

- cognitive: a body of knowledge, skills and abilities necessary to learn about a foreign culture and, at the same time, incorporated within difference competencies (language, communicative, conversational, etc.);

- psychological: the willingness to perform intercultural communication and understand a foreign culture; 
- value-specific: the values that regulate an individual's behavior;

- communicative: the use of language in practice and the experience of intercultural interaction;

- professional: the knowledge, skills, abilities and personal qualities necessary to solve professional problems;

- reflective: the conscious attempts to change one's behavior before, during and after intercultural communication

Kostyukova \& Morozova (2011) discussing the structure of communicative competence point out its components such as professional and linguistic knowledge and skills, professionalpersonal qualities and experience of professional foreign language communication. These components imply the development of theoretical, technological and professional willingness of a student to perform intercultural communication.

The closest to the content of our work is the research conducted by Mikhailova (2012) and her colleagues who have studied the development of professional-language competency in future engineers with the use of ICTs. Further, the applicability of their research results to our study is discussed.

The theoretical basis of Mikhailova's original model comprises a set of methodological approaches (student-oriented, contextual, interdisciplinary, etc.) and principles (activitybased, of autonomous learning, of profession-oriented learning, etc.). Profession-oriented nature of learning has been introduced by including in the discipline that the students studied, "English language", problem-solving tasks related to professional communication which were linked to the other profession-oriented disciplines, such as mechanics, electrical engineering and so on. In this study, a complex of different ICT tools has been used, including blogs and web-services (e.g., online translators and search engines).

Professional-language competency the development of which was the Mikhailova's research object has been defined as "the ability and willingness of future specialists to solve 
communication problems in their professional sphere speaking in a foreign language with native speakers, searching and analyzing information necessary to study foreign experience; deal with scientific and technical literature written in a foreign language related to future specialists' major using ICT tools" (Kruchinina \& Mikhailova, 2012, p. 28).

There are several details that we must attend to, as they help us specify the structure of profession-oriented competence used in our research. "Competency" (kompetentnost in Russian), although a more correct concept would be "competence" (kompetentsia in Russian), in Mikhailova's interpretation: a) includes FLCC ("to solve communication problems", "deal with [...] literature"), b) has a clear practical, professional focus in terms of solving scientific and technical problems, c) implies developed analytical and other thinking skills ("searching and analyzing information", "deal with [...] literature"), d) requires basic skills of ICT use. Another aspect of professional-language competency, according to Mikhailova, implies it having an invariant (basic, everyday communication) and variative (professional communication and problem-solving) parts which correspond to analogous parts in FSES HE for engineering programs. This aspect must be considered important for our research, insofar as having a variative part in the structure of competence enables us to introduce individual educational trajectories for future bachelors which would correspond to their needs (e.g., continuing studies in master programs, or getting an engineering profession).

Furthermore, the Mikhailova's competency comprises the following three components:

- motivation- and value-based, related to raising the students' awareness of their professional language activity and its importance for their future job;

- cognitive- and activity-based, combining the development of FLCC, information and general-professional competencies;

- emotion- and will-based, focused on the learners' reflection and adequate assessment of the results of their own activities (Mikhailova, 2012).

The weaknesses of such a structure and the Mikhailova's research as a whole are the complexity of objective, quantitative evaluation of the aforementioned components, except cognitive- and 
activity-based one, and, what is even more important, the irrelevance of such evaluation to the research objectives the author of this study points out.

Our study's advantage is having a quantitative evaluation of a level of professional language competence development in students based on the qualimetric approach which is used, among other issues, to specify the structure that allows this type of evaluation and takes into account the peculiarity of the students' training program.

With that, it is worth considering that the concept "professional language competence" used in our research addresses the interpretations of categories from the competency-based approach given by the following authors:

- Hutmacher (1997) who claimed that competency is competence "in action";

- Chomsky (2014) who viewed competency as performance, the observed and evaluated real use of competence;

- Subetto (2009) who showed that competency is a set of actualized competence components in action and identifies the degree of this actualization.

For foreign language competence, the use of a characteristic "professional" emphasizes the fact that it determines "the ability and willingness of future specialists to solve communication problems [using a foreign language]", in particular, "in their professional sphere" (Kruchinina \& Mikhailova, 2012, p. 28).

Thus, the analysis of scientific pedagogical literature and dissertations shows that the structure of professional language competence of a technical university student who participates in the bachelor program 11.03.03 "Design and Technology of Electronic Instrumentation" must have the following three components which meet the requirements of the FSES HE (Federal state educational standard of higher education, training program 11.03.03 "Design and technology of electronic means (bachelor's level)", 2015):

- communicative: characterizes the student's ability to comprehend foreign-language 
texts and use lexical and grammatical structures adequate to a professional or learning situation (universal competencies \#3, 4 and 5 from the FSES HE);

- cognitive: reflects the ability of self-learning, self-organization, searching, analyzing and synthesizing profession-oriented information, in English in particular (universal competencies \#1, 2 and 6, general-professional competencies \#3 and 4 from the FSES HE);

- domain-specific: points out the ability to use the professional knowledge to solve communication tasks.

In addition, the domain-specific component includes two individual educational trajectories which correspond to the needs and inclinations of future tool-making graduates:

- scientific: emphasizes the development of: the skills of analyzing scientific and technical information, Russian and foreign experience on a research topic; the ability to produce reports, write scientific papers and prepare presentations about the results of a project competed or a study conducted;

- engineering: covers the development of an ability to translate and make project and technical documentation, in English in particular.

It is believed that allowing students to choose an educational trajectory would help them determine their preferred type of future professional activity each of which has its own distinctive features and, therefore, requires distinct professional language training.

Our experience has shown that the choice of the scientific trajectory is usually caused either by a student's desire to enter a master program and, potentially, a post-graduate program or by one's interest towards professional activity in a research-and-development department.

Otherwise, the engineering trajectory is chosen by future engineers who would have to deal with technical documentation and use a foreign, in most cases English, language in their professional activity (e.g., in business communication with foreign partners or in attending further education online-courses at foreign colleges or organizations). 
It should be mentioned that the objectives of each trajectory match professional competencies and tasks specified in the FSES HE (Federal state educational standard of higher education, training program 11.03.03 "Design and technology of electronic means (bachelor's level)", 2015) as well as job functions specified in a number of professional standards (Professional standard "Adjuster of radioelectronic equipment and devices", 2014; Professional standard "Design engineer in telecommunications", 2014; Professional standard "Radioengineer in aerospace industry", 2015) related to a certain training program. In other words, these educational trajectories fully correspond to the main type of professional activities of toolmaking engineering graduates with a bachelor's degree.

Also, it is worth pointing out that the distinction between communicative, cognitive and domain-specific components in the structure of professional language competence does not imply their factual separate nature in the process of its development. On the contrary, the processes of thinking (cognitive component), speech (communicative component) and professional training (domain-specific component) are closely intertwined interacting with each other.

This three-level structure of professional language competence has been approved by experts via the method of group expert evaluation (Shikhova \& Shikhov, 2013).

\section{Theorethical discussion}

Conditions and stages of competence Development

In this section, the conditions and stages of development of professional language competence in future tool-making engineers are discussed. It must be clarified in advance that the authors below use in their research the concept of FLCC or foreign language competence as part of the professional competence of a technical university graduate. In order to find out the characteristics of the development of professional language competence, in our case, this distinction is considered not critical, as among all the conditions and stages only those would be taken into account which are relevant to the context of our research. 
Verbitsky \& Tehnischeva (2007), as a result of their long-term experiments, points out one crucial condition of foreign language competence development in future engineers - the fact that their professional language training should be based not only on traditional language materials and the practice of all types of speaking activity (speaking component of FLCC), but also, more importantly, authentic domain-specific materials and modelled processes typical of their professional activity where a foreign language is just an instrument used in this activity. Only in such a profession-oriented environment it is possible to have "the substantial integration of modelled professional and real communication activity of language learners" (Verbitsky \& Tehnischeva, 2007, p. 31), only so can profession-related, speaking and sociocultural components of a general-professional competence of a future graduate be connected and transformed into one's ability and, then, willingness to perform the engineering activity.

Chichilanova (2010) in her study discussed the conditions of foreign language competence development in the context of future engineers' professional training as follows: step-by-step execution of communication-based tasks, stimulation of students' reflective activity over the course of their our-of-classroom work, connection of learning to practice which stimulates students' independent work while giving them a right to choose the content of learning tasks.

In this research, students' activity has been assessed by three factors: a) the level of communication skills developed, b) the level of motivation towards foreign and intercultural communication, c) the level of skills developed to manage their classroom and out-of-classroom activities.

Andrienko (2007) having studied the development of the professional communication competence of technical university students distinguished its necessary conditions as follows:

- use of ICT tools;

- organization of students' independent project work;

- use of student-centered, competency-based and professional-activity approaches which in their unity lead to the enhanced motivation, higher level of competencies developed and 
development of professionally significant qualities necessary for successful intercultural communication;

- introduction of the criteria for assessment of the level of competencies developed;

- control and diagnostics of the level of competencies developed and the dynamics in students' professional interests;

- development of student-centered educational trajectories given the peculiarities of professional disciplines studied (this also reaffirms the need for individual trajectories in our structure of professional language competence).

The efficiency of this set of conditions, according to Andrienko (2007), depends on the following parameters which must be regularly measured: the level of students' motivation to future professional activity, given their goals and preferences; the level of information competence (i.e. ability to work with information); how satisfied students are with teaching methods; dynamics of students' general accomplishments and self-esteem. In her teaching experiment, the growth of all these parameters, when the conditions above were established, has been evident.

Kostyukova \& Morozova (2011) in their research divided the same conditions into didactic (variative profession-oriented content of a discipline), academic (composing a teaching package for the competence development) and organization-technical (use of ICTs for selfeducation in terms of professional training).

Note the importance of such conditions, specified by the authors above, as control of students' activity, regular feedback, use of authentic profession-oriented content and introduction of ICTs. Their result must be the increase in students' intrinsic motivation towards self-learning and practical activities.

Furthermore, in scientific pedagogical literature there have been attempts to determine the optimal sequence between the stages of development of foreign language competence for technical university students. For instance, according to Chichilanova's methodology, the process of competence development includes the following stages: 
1) motivation-learning stage: the shaping of students' motives, goals and methods of acquiring knowledge, performing learning and out-of-classroom exercises, the correction of goals and methods depending on the results of diagnostics;

2) cognitive-activity stage: the development of thinking, memory, speech and other cognitive abilities when reproductive-practical exercises are performed;

3) reflective-assessment stage: the development of skill to give an objective assessment of one's own results;

4) adding complexity to the activity: the formation of a creative attitude towards solving professional problems, solving creative tasks.

Frolova \& Aleshchanova (2007) studied the stages of technical university students' learning a foreign language using as examples the tasks of:

- reviewing, creative and analytical speech-thinking process which engages a student's linguistic competence;

- annotating, brief description or presentation of information from the primary source.

Note that both of these tasks have a lot in common with blogging, key learning tool used in our research. Describing the algorithm of teaching students how to review and annotate texts as a cycle, the authors distinguish the following four stages:

1) motivation-guiding, which actualizes the motivational basis of learning a foreign language;

2) goal-setting, during which a teacher in cooperation with each student specify the relevant goals of their learning of how to write a review and annotation to an authentic source, select the materials for this work;

3) teaching-learning, which implies the student's acquisition of professional vocabulary and the development of practical skills and abilities they have acquired before (the support 
of teachers from students' major's department with the purpose of their professional orientation);

4) resulting, which means the systematization of knowledge by students and quality control of its acquisition performed by a teacher.

Apart from this, Aleshchanova (2006) suggested a plan for presenting the information in reviewing in English which comprises three stages: 1) understand the situation: identify the topic and object of the text, as well as space-time boundaries; 2) identify the problem and idea of the text; 3 ) analyze the text and make conclusions based on this analysis. These steps, in her opinion, enable organizing the complete process of comprehension of an authentic text written in a foreign language.

Mukharkina (2008) in her study divides the development of intercultural professionalcommunication competence into the following stages:

1) orientation-introductory: designed to shape the attitude towards the development of the competence, as well as giving the idea of future intercultural interaction in order for students to articulate their value-based attitude to this interaction and activate their background knowledge;

2) practice-oriented: necessary to deepen the knowledge, abilities and skills of a future specialist who is engaged in the process of learning about a foreign culture and compares its models of professional behaviour with its equivalents in one's own culture;

3) professional-value-based: important for experiencing intercultural professional communication during which a student learns to predict the consequences of differences the interacting cultures have, as well as to solve possible conflicts.

Albrekht \& Kondurina (2013) in their study on the development of professional mobility in students from a non-linguistic university distinguish three stages: 1) stabilizing: moving towards stable functioning in a learning environment; 2) analytical: reflection about one's own activity; 3 ) transformational: stable development in a learning environment. 


\section{Methodology}

The main objective of this study has been to develop a pedagogical model based on the literature review above. This model is focused on organizing independent work of technical university undergraduates with ICTs. Some of the key elements of this model are presented in the conclusion to this paper.

The methods used at this stage of the research are an analysis of pedagogical concepts, such as competence, and synthesis of the approaches in order to build the foundation for the model mentioned. The question the author is concerned in this study is how to optimize the organization of independent work for technical university students whose objective is to develop professional language competence.

To resolve this question, not only qualitative methods are used. The qualimetric approach and the method of expert group appraisal as part of this approach are used in order to quantitatively measure the level of development for students' professional language competence before and after the model is applied to their training process. The model's components, as well as the criteria based on which the level of student's professional language competence, are determined are also established with expert group appraisal.

As part of another literature review, the basic teaching tool around which the independent student work has to be organized, according to this model, is profession-oriented blogging.

\section{Study design}

After the structure of professional language competence has been identified, its components must be subdivided into a number of basic skills based on which experts, i.e. teachers and practitioners having a significant amount of expertise in professional English language, make conclusions about the level of students' competence.

Given that blogging has been chosen as the learning tool for this research, there are three pedagogical objects that must be assessed within the framework of the model's methodology:

1) student's blog on a professional topic in English which they keep during a semester. It is assessed based on the quality of grammar and vocabulary used there, logical coherence 
of the content presented in a blog, the regularity of blog posts, absence of plagiarism, ability to use professional terms in English and the relevance of the topic chosen.

2) student's final presentation of one's blogging results. It is assessed by the quality of grammar and vocabulary in one's oral speech, the depth of his understanding of the topic studied, whether the blogging results match the content of the presentation and whether a student can speak about professional problems discussed in his blog.

3) student's professional thesaurus, i.e. one's profession-related vocabulary which is used in a blog and consists of professional terms and their definitions. A thesaurus is assessed by how accurate definitions are with respect to the terms written and whether a half of this vocabulary matches the basic thesaurus for a given training program (in this study for the bachelor program 11.03.03 "Design and Technology of Electronic Instrumentation" the basic thesaurus has been composed in collaboration with teachers from Instrumentation department in our university).

The qualitative assessment of the mentioned criteria for these three objects is regularly monitored and controlled by a teacher in order to provide feedback and guide students towards the development of their professional language competence.

\section{Recommendations}

Certain limitations have been discovered while testing the model mentioned that must be taken into account. The most important among them is too much time and effort that all parties have to spend on their work. Experts have to spend a few hours on assessing the quality of students' blogs, presentations and thesauruses. A teacher has to regularly monitor students' progress and follow their updates in their blogs, provide constant feedback to students in and out of the classroom whenever it is necessary. Students have to spend hours every week, especially at the initial stage of their blogging, to teach themselves and gain experience of how to optimize their workflow: searching for next blog post topics, studying a lot of material in English, composing a plan and content of their publication. 
Partly this limitation is eliminated by the use of additional software that could automate these processes. For instance, grammar-checking software like Grammarly and Hemingway allow experts to determine the quality of a blog's grammar and vocabulary by putting the text into these programs. Anti-plagiarism and search engines allow them also to check whether the content of blog posts is copied and pasted without changes from a website.

Students' concerns tend to be more individual and require a teacher to be ready to guide and optimize students' work processes so that they feel neither overwhelmed nor too relaxed by blogging. This independent work should demand their regular attention and effort without the pressure that they cannot handle by themselves. In any case, it is up to the teacher to organize learning environment, both in classroom and online, so that student bloggers, if they experience trouble, are always willing to ask for help from their peers and from their teacher.

\section{Conclusion}

Summarizing the aforementioned approaches to the step-by-step development of students' professional language competence, the structure of which has been determined earlier, a conclusion can be made that, in the context of our research, it is reasonable to follow the stages below:

a) preparation, at which the goals of learning activity relevant to a student must be set in cooperation with a teacher to establish the environment where students' intrinsic motivation would drive their activity;

b) activity, regulating a student's learning activity and a teacher's pedagogical activity taking into account the learning objectives and the means towards their achievement, as well as the characteristics of a region, educational institution and learners' contingent;

c) reflection, which implies students' reflective thinking, self-assessment and their mutual assessment, as well as assessment by experts, of the results of students' work in order to make a conclusion about the level of their current competence development so that their educational trajectories can be corrected whenever necessary; 
d) discussion, during which the results of students' work are discussed by students and a teacher.

The pedagogical conditions that must be established in order to create the learning environment for students are as follows:

1. timely and regular feedback between a teacher and students;

2. use of authentic profession-oriented materials in English;

3. design of individual educational trajectories with respect to students' goals and preferences;

4. ability and willingness of a teacher to organize students' independent work based on ICT tools (in our research, this means the willingness to organize this work based on profession-oriented student blogging);

5. control of students' independent work by a teacher.

In conclusion, it must be emphasized that the components of professional language competence in future technical university graduates are developed not simultaneously, but in an interrelated and systemic way. As the relevance and amount of students' independent work grow, this fact should be taken into consideration before such work is organized, in particular for more efficient use of ICT tools like profession-oriented blogging.

\section{References}

Albrecht, N. V. \& Kondrina, I. M. (2013). Foreign Language communication as a tool of development of professional mobility of students from non-linguistic university: monograph [Inoyazychnaya kommunikatsiya kak sredstvo razvitiya professional'noj mobil'nosti studentov neyazykovogo vuza: monografiya], 242 p. (in Russian)

Aleshchanova, I. V. (2006). Narrative competence in speech behavior of personality [Narrativnaya kompetentsia v rechevom povedenii lichnosti]. Izvestia Volgograd State Technical University, 6, 100-102. (in Russian) 
Andrienko, A. S. (2007). Razvitie inoyazycnnoy professionalnoy kommunikativnoy kompetentnosti studentov tekhnicheskogo vuza (na osnove kreditno-modulnoy tekhnologii obucheniya). [Development of foreign language professional communicative competence of the technical college students (on the basis of credit-and-unit technology training)]. PhD thesis, Rostov-na-Donu, 282 p. (in Russian)

Baidenko, V. I. (2005). Bolonskii protsess: seredina puti [Bologna Process: The Midway]. Moscow: Research Center for Quality Problems in Specialist Training, Russian New University. 379 p. (in Russian)

Chichilanova, S. A. (2010). Foreign communicative competence forming of students from technical institution of higher education in a process extracurricular self-dependent work: PhD thesis, Chelyabinsk, 195 p. (in Russian)

Chomsky, N. (2014). Aspects of the Theory of Syntax. MIT press, 11.

Galyamina, I. G. (2004). Proektirovaniye gosudarstvennykh obrazovatelnykh standartov vysshego professionalnogo obrazovaniya novogo pokoleniya s ispolzovaniyem kompetentnostnogo podkhoda [Design of state educational standards of higher education of new generation with competency-based approach]. Moscow: Research Center for Quality Problems in Specialist Training, Russian New University, 1(49), 285-297. (in Russian)

Gareyev, A. A., Shikhova, O. F., \& Shikhov, Yu. A. (2018). Organization of independent student work based on student blogging activity. Education and Science journal [Obrazovanie i nauka]. 20(3), 117-136. (in Russian)

Gez, N. I. \& Frolova, G. M. (2008). Istorija zarubezhnoj metodiki prepodavanija inostrannyh jazykov [The History of Teaching Foreign Language Methods], Moscow: Academy, 256 p. (in Russian) 
Federal state educational standard of higher education, training program. (2015). 11.03.03 "Design and technology of electronic means (bachelor's level)", approved by the Ministry of education and science of Russian Federation, November 12, 2015, N 1333. (in Russian)

Frolova, N. A. \& Aleshchanova, I. V. (2007). Teaching to abstract and annotate professional texts in foreign languages in complex training of specialists [Obuchenie referirovaniyu i annotirovaniyu professional'noj literatury na inostrannom yazyke v kompleksnoj podgotovke spetsialista]. Modern problems of science and education [Sovremennye problemy nauki i obrazovaniya], 5, 11 p. (in Russian)

Hutmacher, W. (1997). Key competencies in Europe. European journal of education. 32(1), 45-58.

Kostyukova, T. A. \& Morozova, A. L. (2011). Development of foreign language Communication competence of students from non-linguistic universities: monograph [Razvitie inoyazychnoy kommunikativnoy kompetentnosti studentov neyazykovykh vuzov: monografiya]. Tomsk: Tomsk. politekh. universitet. 119 p. (in Russian)

Kruchinina, G. A. \& Mikhailova, E. B. (2012). Forming professional foreign language competence in students of engineering specialities under the conditions of informatization of higher professional education [Formirovanie professional'no-inoyazychnoj kompetentnosti studentov inzhenernykh spetsial'nostej v usloviyakh informatizatsii vysshego professional'nogo obrazovaniya]. Bulletin of Lobachevsky Nizhny Novgorod University, 4(1), 26-33. (in Russian)

Medvedev, V. \& Tatur, Y. (2007). Training of university teachers: competence based approach. Vysshee obrazovanie v Rossii [Higher education in Russia], 46-56. (in Russian)

Mikhailova, E. B. (2012). Formation of professional-foreign competence in students of engineering specialties using the means of information and communication technologies [Formirovanie professional'no-inoyazychnoj kompetentnosti studentov inzhenernykh spetsial'nostej s ispol'zovaniem sredstv informatsionnykh i kommunikatsionnykh tekhnologij]. PhD thesis, Nizhny Novgorod, 293 p. (in Russian) 
Mukharkina, S.A. (2008). Intercultural communication-professional competence forming of a specialist in a postindustrial society. Izvestiia Rossiiskogo gosudarstvennogo pedagogicheskogo universiteta im. AI Gertsena [Izvestia: Herzen University Journal of Humanities \& Science], 65. (in Russian)

Petrova, I., Zaripova, V., \& Ishkina, E. et al. (2013). Tuning Russia: Reference points for the design and delivery of degree programs in information and communication technologies. Bilbao: University of Deusto. 86 p. (in Russian)

Prahova, M. Y., Zaichenko, N. V., \& Krasnov, A. N. (2015). Evaluation of formation of professional competence. Vysshee obrazovanie v Rossii [Higher Education in Russia], 2, 21-28. (in Russian)

Professional standard "Design engineer in telecommunications". Approved by the decree of the Ministry of Labour and Social Protection of the Russian Federation No. 316n of 19 May 2014. (in Russian)

Professional standard "Adjuster of radioelectronic equipment and devices". Approved by the decree of the Ministry of Labour and Social Protection of the Russian Federation No. 531n of 4 August 2014. (in Russian)

Professional standard "Radioengineer in aerospace industry". Approved by the decree of the Ministry of Labour and Social Protection of the Russian Federation No. 971n of 3 December 2015. (in Russian)

Shikhova, O. F. \& Shikhov, Yu. A. (2013). “Qualimetric approach to diagnostics of graduates' competences of the higher school". Education and Science journal [Obrazovanie $i$ nauka], 4, 40-58. (in Russian)

Subetto, A. I. (2009). The ontology of the competence-based approach in educational systemology. Siberian Pedagogical Journal, 1, 100-126. (in Russian) 
Tatur, Y. G. (2004). Competency-based approach in the describing the results and design of higher education standards. Proceedings of the second meeting of the methodological seminar, Moscow, 17 p. (in Russian)

Tayurskaya, N. P. (2015). Foreign language communication competence [Inoyazychnaya kommunikativnaya kompetentsiya: zarubezhnyj i rossijskij opyt]. Humanitarian vector. Series: Pedagogy, psychology, 1(41), 83-87. (in Russian)

Verbitsky, A. A. \& Tenischeva V. F. (2007). Foreign competencies as the component of general professional competency of engineer. Vysshee obrazovanie segodnya [Higher education today], 12, 27-31. (in Russian)

Vygotsky, L. S. (1997). The collected works of L. S. Vygotsky: Problems of the theory and history of psychology, Springer Science \& Business Media, 3, 426 p.

Zeer, E. F. (2005). Competence-based approach to education. Obrazovanie i nauka. [The Education and Science Journal], 3(33), 27-40. (in Russian)

Zeer, E. H. \& Symaniuk, E. H. (2005). Competency-based approach to modernization of higher education. Vysshee obrazovanie v Rossii [Higher education in Russia], 4, 2228. (in Russian)

Zimnyaya, I. A. (2004). Key competencies as effectively-targeted base of competency-based approach in education. Moscow: Research Center of the problems of the quality of specialist's training, 42 p. (in Russian) 